\title{
Social participation: a look at the representativeness of health councils in Brazil, from Resolution 453/2012
}

| ${ }^{1}$ Rita de Cássia Costa da Silva, ${ }^{2}$ Maykon Anderson Pires de Novais, ${ }^{3}$ Paola Zucchi I

Abstract: The text addresses the representativeness in health councils in Brazil, based on guidelines proposed by the National Health Council. This study aimed to verify the adequacy of the councils to the criteria described in Resolution 453/2012, which demonstrate the representativeness of the segments that make up the collective. A descriptive cross-sectional study was conducted during May and June 2017. The study population was composed of health councils registered in the Health Councils Monitoring System, with public access and available on the Internet. The results obtained were organized considering the geographical distribution of the councils. The regions with the highest rates of noncompliance with the parity criterion were identified. It has been demonstrated that the guidelines for reformulating the councils are aligned with the notion of representativeness, but they are not a guarantee for the effectiveness of the representation. Future studies may deepen the analyses on representativeness in health councils in Brazil, and identify which mechanisms are adopted by entities to ensure the effectiveness of representation, as well as whether representation is renewed. It is recommended that the rules ordering the functioning of councils be permanently updated to promote social participation in health.

> Keywords: Health councils. Community participation. Unified Health System. Brazil.

\author{
1 Universidade Federal de São \\ Paulo. São Paulo-SP, Brasil \\ (magripe@gmail.com). \\ ORCID: 0000-0002-3135-371X \\ 2 Universidade Federal de São \\ Paulo. São Paulo-SP, Brasil \\ (amaykon@gmail.com). \\ ORCID: 0000-0001-8069-4927 \\ ${ }^{3}$ Universidade Federal de São \\ Paulo. São Paulo-SP, Brasil \\ (pzucchi@unifesp.br). \\ ORCID: 0000-0002-0672-1584
}

Recebido em: 05/08/2019

Aprovado em: 17/01/2020

Revisado em: 18/05/2021 


\section{Introduction}

In recent years, social participation in public policy councils has been widely disseminated in Brazil and several Latin American countries (GURZA LAVALLE; ISUNZA VERA, 2010). The representativeness in public policy councils highlights the expansion of democratic processes, especially regarding the presence of civil society. The councils prove that representation is an important attribute of democratic processes (SANTOS; AVRITZER, 2003).

In Brazil, representativeness is a prominent factor in the field of public health, and social participation is one of the guidelines of the Brazilian Unified Health System (Sistema Unico de Saúde - SUS) (BRASIL, 1988). In this context, the theme of representativeness echoes as a current and necessary discussion to understand the dynamics of health councils. Previous studies, based on case studies, have evidenced aspects related to the legitimacy of representation in councils and the understanding of social actors about their role and the representativeness of participatory instances in the Unified Health System (REZENDE; MOREIRA, 2016; JUNIOR BISHOP; GERSCHMAN, 2015; MÜLLER NETO; ARTMANN, 2014). In this study, the scope was expanded to adopt, as units of analysis, all health councils in Brazil and their relations with the national guidelines that order their functioning.

Through Resolution 453/2012, the National Health Council (NHC) established parameters for the development of council activities that can be understood from the concept of sociological representativeness, proposed by Archanjo (2011). The elected councilors are signatories of the interests of those they represent and, therefore, can act in the supervision and deliberation of public health policy. However, when there is no engagement and participation of the represented, there is a distancing between the councilors and their bases (VENTURA et al., 2017). The normative in question indicates that representation in the councils should be through the presence of entities (associations, social movements, civil organizations, unions, federations, class councils, scientific community, public entities, employers, and service providers) and government representatives (BRASIL, 2012). In the governmental instance, representatives of the Executive Branch (minister or secretaries of health) appoint the councilors. The councilors representing civil society (users, workers, and service providers) must be elected in a forum specially called for this purpose, which will indicate the entity that will occupy the vacancy for the respective segment. 
Similarly, other guidelines included in Resolution 453/2012 refer to the issue of representativeness in the field of public health policy. The parity criterion for the councils' composition and the holding of elections also contributes to ensuring representation and balance of forces between civil society and government in decision-making. Thus, the document states that the councils must be organized with a parity composition, that is, $50 \%$ of the components must necessarily be representatives of users of the Unified Health System and the remaining 50\% will be equally distributed among workers, managers, and service providers in the public health area. In addition, the councils must have a president elected among their members, in a plenary meeting.

The aspects highlighted above are in line with the need to address the ongoing challenges for effective social participation in the health sector. The issue of low representation in the councils stands out as one of the main obstacles to be overcome (GUIZARDI, 2015). In this perspective, it is relevant to discuss representativeness in the councils, from the criteria provided in Resolution 453/2012, a document that orders the operation of all health councils implemented in Brazil. Therefore, this research aimed to verify whether the health councils are adequate to the criteria described in Resolution 453/2012, which demonstrate the representativeness of the segments that make up the collective: parity, entities representing the user, worker, and service provider, election for president, and president's segment. The article describes the scenario of health councils at the national level, based on an analysis that characterized the variables studied in all Brazilian regions.

\section{Material and methods}

A descriptive, cross-sectional study was carried out. This type of study allows visualizing the situation of a population at a given time (ROUQUAYROL; ALMEIDA FILHO, 2006). In addition, they are of a better application for descriptive approaches, allowing to address well-defined populations through sampling (SANTANA; CUNHA, 2014).

The study population was composed of health councils in Brazil registered in the National Health Council's information system, with data updated until April 2017. A secondary data source was used, through electronic research in the Health Council Monitoring System (SIACS), which composes a unique data network with 
information about the composition and compliance with legal norms for social participation in the Unified Health System.

SIACS is a public access database, available on the Internet, which contains information about the health councils in Brazil. The health councils do registration in SIACS upon request for access to the system, and subsequent issuance of an exclusive password by the NHC, so that each council can register the information required to compose the database. It has been running since 2012 to show "the composition of collegiate bodies and compliance with legal norms related to the Unified Health System" (BRASIL, 2012b).

Data were collected in May and June 2017, in an individualized format, i.e., recorded for each unit of analysis singularly and organized according to the geographical distribution of Brazil (IBGE, 1977). As an eligibility criterion, it was adopted to be registered in SIACS in the collection period. Health councils not registered in SIACS were excluded from the study.

Based on Resolution 453/2012 of the NHC, a set of qualitative variables that are characteristics or attributes of interest was defined to characterize the reformulation strategies adopted by the health councils. The study considered the following variables: parity; the presence of entities, institutions, and movements representing users, workers, and health service providers in the composition of the council; election for president, and segment of the president.

The results were organized considering the geographical distribution of the councils. Descriptive statistic was used in the data analysis, comprising the following steps: data organization, simple tabulation, preparation of frequency tables, graphical representation to relate categories, and indicate the presence or absence of variables of interest.

Data interpretation considered the findings in the literature and the guidelines expressed in Resolution 453/2012 of the National Health Council.

\section{Results}

The study sample consisted of 4,742 health councils registered in SIACS, representing $84.21 \%$ of the 5,631 existing in Brazil. Another 889 (15.79\%) councils were excluded from the study for not being registered in SIACS at the time of data collection. The variables were analyzed to identify the adequacy of Resolution $453 / 2012$ and, consequently, to evidence the representativeness of the councils. 


\section{Parity}

The study identified that 3,097 councils (65.30\%) are adequate regarding the parity criterion proposed in Resolution 453/2012. The number of non-parity councils was $1,579(33.30 \%)$. It is noteworthy that $66(1.40 \%)$ councils failed to inform the presence of parity in their composition. The councils with the highest rates of inadequacy to Resolution 453/2012, to the parity criterion, are located in the South (10.52\%), Northeast (9.25\%), and Southeast (8.43\%) (Table 1).

Table 1. Parity in the composition of health councils, by Region

\begin{tabular}{lcccccccc}
\hline Region & \multicolumn{2}{c}{ Yes } & \multicolumn{2}{c}{ No } & \multicolumn{2}{c}{ Uninformed } & \multicolumn{2}{c}{ Grand Total } \\
\hline North & $\mathrm{N}$ & $\%$ & $\mathrm{~N}$ & $\%$ & $\mathrm{~N}$ & $\%$ & $\mathrm{~N}$ & $\%$ \\
\hline Northeast & 252 & 5,32 & 100 & 2,11 & 10 & 0,21 & 362 & 7,65 \\
\hline Southeast & 1.142 & 24,08 & 439 & 9,25 & 19 & 0,40 & 1.600 & 33,74 \\
\hline South & 803 & 16,93 & 400 & 8,43 & 18 & 0,38 & 1.221 & 25,75 \\
\hline Midwest & 642 & 13,53 & 499 & 10,52 & 14 & 0,30 & 1.155 & 24,35 \\
\hline Total & 258 & 5,44 & 141 & 2,99 & 05 & 0,11 & 404 & 8,51 \\
\hline Source: Heath & 3.097 & $\mathbf{6 5 , 3 0}$ & $\mathbf{1 . 5 7 9}$ & $\mathbf{3 3 , 3 0}$ & $\mathbf{6 6}$ & $\mathbf{1 , 4 0}$ & $\mathbf{4 . 7 4 2}$ & 100,00 \\
\hline
\end{tabular}

Source: Health Council Monitoring System (SIACS)

Among the 1,579 non-parity councils, it was identified that the management segment is the most present in the North, Northeast, and Southeast regions. In the South region, there is a greater presence of users. In the Midwest, workers are the most represented segment. 156 councils did not report the number of representatives of each segment.

\section{Presence of entities, institutions, and representative movements of users, workers, and health service providers}

Resolution 453/2012 of the NHC indicates that the representation of users, workers, and service providers should take place through the presence of representative entities and recognized coverage in the territories, ensuring the complementarity of society as a whole in decisions on health policy. It points out that in municipalities where entities, institutions, or movements organized to form the Council are not 
identified, the representatives should be elected in a plenary session organized broadly and democratically.

The great majority of the health councils in all Brazilian regions are following the recommendation of the NHC and declares the presence of representative entities in the composition for the segments of users, workers, and health service providers. As for users and service providers, the entire sample in Brazilian regions includes representative entities in the councils' composition. In the workers' segment, it was found that only $66(1.40 \%)$ of the 4,742 councils studied do not have representative entities in their composition. In these cases, the working councilor is not linked to a collective, therefore, the vacancy in the council is not occupied by the entity, but by the individual (Table 2).

Table 2. Presence of representative entities in health councils, by segment and Region

\begin{tabular}{|c|c|c|c|c|c|c|c|c|c|c|c|c|}
\hline \multirow{3}{*}{ Region } & \multicolumn{4}{|c|}{ User } & \multicolumn{4}{|c|}{ Worker } & \multicolumn{4}{|c|}{ Service provider } \\
\hline & \multicolumn{2}{|c|}{ Yes } & \multicolumn{2}{|c|}{ No } & \multicolumn{2}{|c|}{ Yes } & \multicolumn{2}{|c|}{ No } & \multicolumn{2}{|c|}{ Yes } & \multicolumn{2}{|c|}{ No } \\
\hline & $\mathrm{N}$ & $\%$ & $\mathrm{~N}$ & $\%$ & $\mathrm{~N}$ & $\%$ & $\mathrm{~N}$ & $\%$ & $\mathrm{~N}$ & $\%$ & $\mathrm{~N}$ & $\%$ \\
\hline North & 362 & 7,63 & - & - & 352 & 7,42 & 10 & 0,22 & 362 & 7,63 & - & - \\
\hline Northeast & 1.600 & 33,75 & - & - & 1.581 & 33,34 & 19 & 0,40 & 1.600 & 33,75 & - & - \\
\hline Southeast & 1.221 & 25,74 & - & - & 1.203 & 25,37 & 18 & 0,38 & 1.221 & 25,74 & - & - \\
\hline South & 1.155 & 24,36 & - & - & 1.141 & 24,06 & 14 & 0,29 & 1.155 & 24,36 & - & - \\
\hline Midwest & 404 & 8,53 & - & - & 399 & 8,41 & 5 & 0,11 & 404 & 8,53 & - & - \\
\hline Total & 4.742 & 100,00 & - & - & 4.676 & 98,60 & 66 & 1,40 & 4.742 & 100,00 & - & - \\
\hline
\end{tabular}

Source: Health Council Monitoring System (SIACS)

\section{Election and segment of the president}

Among the health councils studied, 4,191 (88.39\%) conduct elections for the president's choice. The presence of 441 councils (9.30\%) distributed throughout all Brazilian regions that do not hold elections for president and, therefore, are not adequate to the recommendations of Resolution 453/2012. Another 110 councils (2.31\%) did not declare the information (Table 3 ). 
Table 3. Election for president of health councils, by Region

\begin{tabular}{lllllll}
\hline Region & Yes & \multicolumn{3}{c}{ No } & \multicolumn{3}{c}{ Uninformed } \\
\hline & $\mathrm{N}$ & $\%$ & $\mathrm{~N}$ & $\%$ & $\mathrm{~N}$ & $\%$ \\
\hline North & 330 & 6,96 & 21 & 0,44 & 11 & 0,23 \\
\hline Northeast & 1.411 & 29,75 & 147 & 3,10 & 42 & 0,88 \\
\hline Southeast & 1.014 & 21,38 & 175 & 3,69 & 32 & 0,67 \\
\hline South & 1.055 & 22,25 & 81 & 1,71 & 19 & 0,40 \\
\hline Midwest & 381 & 8,05 & 17 & 0,36 & 06 & 0,13 \\
\hline Total & 4.191 & 88,39 & 441 & 9,30 & 110 & 2,31
\end{tabular}

Source: Health Council Monitoring System (SIACS)

The study also identified the segments (user, worker, manager/provider) to which the elected council presidents belong. It was observed that managers/service providers hold the position of president in 1,785 councils (37.63\%). Users assume the presidency in 1,400 (29.52\%) and workers in another 1,324 (27.92\%). The result observed in the regions presents similar characteristics. In the North, Northeast, and Southeast, managers/service providers are the ones who most occupy the position of council president. In the South and Midwest regions, users appear as those who most perform the function of the presidency. In all regions, workers' representatives are the least represented segment in the presidency of the councils (Table 4).

Table 4. Segment of the presidents of health councils, by segment and Region

\begin{tabular}{lcccccccc}
\hline \multirow{2}{*}{ Region } & \multicolumn{2}{c}{ User } & \multicolumn{2}{c}{ Worker } & \multicolumn{2}{c}{$\begin{array}{c}\text { Manager / Service } \\
\text { Provider }\end{array}$} & \multicolumn{2}{c}{ Uninformed } \\
\hline & $\mathrm{N}$ & $\%$ & $\mathrm{~N}$ & $\%$ & $\mathrm{~N}$ & $\%$ & $\mathrm{~N}$ & $\%$ \\
\hline North & 130 & 2,74 & 101 & 2,13 & 116 & 2,43 & 15 & 0,33 \\
\hline Northeast & 292 & 6,16 & 442 & 9,32 & 794 & 16,72 & 75 & 1,58 \\
\hline Southeast & 329 & 6,94 & 334 & 7,04 & 494 & 10,40 & 64 & 1,35 \\
\hline South & 491 & 10,35 & 311 & 6,56 & 291 & 6,13 & 62 & 1,31 \\
\hline Midwest & 158 & 3,33 & 136 & 2,87 & 93 & 1,95 & 17 & 0,36 \\
\hline Total & 1.400 & 29,52 & 1.324 & 27,92 & 1.785 & 37,63 & 233 & 4,93 \\
\hline
\end{tabular}

Source: Health Council Monitoring System (SIACS) 


\section{Discussion}

Brazilian democracy stands out in the international scenario for the breadth and volume of participation channels, which have the function of expanding access to public policies. Social participation in Brazil is inserted in the context of the mobilization for the country's re-democratization, which preceded and culminated in the promulgation of the 1988 Constitution (AVRITZER; MARONA, 2017). The great expansion of public policy councils in Brazil, especially health councils, which have been implemented in all municipalities and states since 1991, is the result of the democratization process that began in the 1970s. In this context, the Brazilian Sanitary Reform movement played a prominent role in mobilizing the population, workers, and managers in defense of health as a universal right (PAIM, 2018). This movement favored the representativeness of social actors in the composition of health councils.

The Federal Constitution, in establishing the SUS, defined the democratic character of its administrative management, contemplating social participation in the monitoring and deliberation on health policy (COTTA et al., 2010). Several authors emphasize social participation as a prominent feature in the management of the Brazilian public system since the 1990s (AVRITZER, 2011; COELHO, 2012; LÜCHMANN et al., 2016).

As in Brazil, social participation is a remarkable characteristic of other health systems in the world. In Central America, for example, countries such as Costa Rica and Guatemala have engaged in efforts to adopt decentralized processes in health policy management, seeking to integrate the community in the development of local projects, with a community focus (RUBIO; UGARTE, 2014). In the Brazilian case "although it is provided for in law, social participation is a process, under permanent construction, which involves advances and setbacks, and often depends on the broad mobilization of the community in defense of its rights" (ROLIM; CRUZ; SAMPAIO, 2013, p. 143).

Health councils, the focus of this study, can be considered political experiences of participatory democracy, which emerged in the claiming context, by right to health. Its institution translates the mobilization of social sectors interested in the implementation of public policies, based on horizontality, inclusion, and direct democracy (SANTOS; AVRITZER, 2003; BONET, 2017). Participatory democracy 
gives citizens the possibility to participate in political decision-making (BUHLUNGU, 2003). In health councils, meetings are public assemblies open to the participation of all stakeholders. Through resolutions, recommendations and motions, the councilors deliberate on public health policy in the three spheres of government.

A study conducted by Dib Zambon and Ogata (2011) highlights that the process of implementation of health councils in Brazil occurred since 1991, enhanced through Basic Operational Health Standards published by the Ministry of Health. Cotta et al. (2011) point out that the existence of health councils in Brazil is a condition and instrument for the construction of the right to health. The authors emphasize that councils constitute an innovation, from the political, institutional, and cultural point of view for the consolidation of the SUS. The importance of public policy councils to exercise control and oversight in democratic governments is recognized (MENDES, 2007). The councils express the necessary complementarity between participatory democracy and representative democracy, since the participation of society is open, where all present have the right to voice. Decisions are made through the vote of the elected representatives and appointed to compose the collective. However, as already widely discussed, the institutionalization of councils, despite being an important strategy for health democratization, "per se, is insufficient for the decision-making process to be effectively democratized" (MOREIRA; ESCOREL, 2009, p. 796).

In Brazil, the routine of health councils is guided by the National Health Council, through Resolution 453, of May 10, 2012, which revoked the previous Resolution 333/2003 and reaffirmed guidelines for the functioning of the councils ensuring effective social control in SUS, under Law 8,142/1990. The document was published to offer guidelines for the institution, reformulation, restructuring, and functioning of the councils. It is the most recent instrument to guide the functioning of the councils, despite their limitations regarding the functional order as already pointed out by Lima (2017). This document established several guidelines, among which we will highlight those that characterize strategies for reformulation: parity, election to president, and presence of representative entities of organized society in the composition of the council (BRAZIL, 2012). In addition, it aims at the primacy of collective interests over individuals ones, with the councilor being linked to a group with whom he assumes the commitment, at the time of its indication, to represent collective interests. 
Studies conducted in Brazil have already highlighted the close relationship between representativeness and effectiveness of participation in health councils. (LUCHMANN, 2007; GURZA LAVALLE, 2006; AVRITZER, 2007; SANTOS, 2011). Cotta (1992), cited by Archanjo (2011) distinguishes three possible concepts to characterize the relationship between representatives and represented: representation as delegation, as trust, and as a mirror or sociological representativeness. The representation understood as delegation involves the idea that someone is delegated to fulfill the will of others, serving as a spokesperson for the represented and promoting the defense of their interests. It is not a question of direct and individualized representation, but about speaking on behalf of a particular group, such as political, religious, professional categories, among others.

The representation considered as a relationship of trust indicates that the representative defends the interests of the represented, but there is no prior link to any prerogative established by the represented. In this case, the representative has the autonomy to make decisions, without requiring the approval of those he represents, but taking into account that the representative perceives and defends the interest of the represented. Finally, representation as a "mirror" focuses on the effects of representative activity that seeks to expand the participation of different social groups, considering the representativeness of those who are elected to represent the population (ARCHANJO, 2011). From this conception, it is obtained that the quality of representation is directly related to opportunities for participation, which must be expanded to reach a greater number of represented people (MIGUEL, 2017).

Among the elements that highlight the representativeness in Resolution $453 / 2012$, the first characteristic concerns the adoption of the parity criterion for the composition of the councils. The concept of parity adopted by the normative is anchored in the concept of democracy proposed by Bobbio (1979), cited by Santos and Avritzer (2003), in which there is a representative balance to ensure equal weight without economic, social, religious, and ethnic distinction among the participants. In this sense, parity establishes equalization of forces between society and government, ensuring that the demands of the population in the organization of public policies are contemplated. The concept of participatory parity proposed by Fraser (2007) is also useful for the analysis of the composition of health councils. According to the author, parity indicates a direct relationship to the notion of recognition as a question of justice, which contemplates social 
status in the sense of participating as an equal in the dynamics of social relations, interacting with others as a pair (FRASER, 2007).

Thus, the situation, revealed in this study, that there are still non-parity councils in Brazil is worrisome. In these cases, in advance, an imbalance of forces persists in the monitoring and deliberations on public health policy, compromising the notion of equal participation. Although parity in health councils is not enough to demonstrate effective social participation in the management of the Unified Health System, the existence of non-parity councils denounces the non-compliance with Law 8,142/1990, which provides for social participation in the management of SUS. The lack of parity suggests an imbalance that compromises decision-making and the processes of monitoring and supervision of health policy. Moreover, the greater presence of managers/service providers in three regions calls into question the supervisory role of health councils, considering that social control presupposes the monitoring of the public managers' performance by representatives of civil society.

The results obtained, about the variable parity, also show the non-compliance with Judgment No. 1,660/2011 of the Federal Court of Auditors (Tribunal de Contas da União - TCU), which determines the Ministry of Health "refrain from transferring values to the federation entities that do not observe parity in the composition of the respective Health Council, to privilege units that are committed to effective social control" (BRASIL, 2011).

Faced with the scenario evidenced by the study, if applied, the TCU's determination could compromise the development of health actions and services in those states and municipalities whose councils are not adequate to the parity criterion.

The recommendation of the NHC values the presence of representative entities in the composition of councils spread throughout Brazil. The results found in all regions are consonant with the findings in the literature. Since the 1990s, several public policy councils were created and adopted this format of representation, established in infraconstitutional regulations (RAMOS et al., 2012). The proposition of Resolution 453/2012 and the findings of this study are aligned with the consensus that associativism is capable to put on the agenda the needs and demands of more vulnerable groups (LÜCHMANN, 2011). It is also noteworthy that Frazer's studies, evidenced by Cardoso (2012), corroborate the indication of Resolution 453/2012, for councils to include representative entities among the vacancies for councils 
composition. The idea of participatory parity translates the "ability to interact in society from a common point, 'with adequate representativeness' (our griffin), and the possibility of influencing political-democratic organizations" (CARDOSO, 2012, p. 111). The presence of entities in the composition of the councils also indicates the representation of organized social groups to define and monitoring of health policy. However, only the presence of representative entities cannot be taken as a guarantee of effective representation, since there is always the risk of co-optation of civil society by hegemonic sectors of the State. Nevertheless, the Brazilian experience is recognized for its innovative character and reference as a model against hegemonic democracy (SANTOS; AVRITZER, 2003).

The existence of parity and the presence of representative institutions among the segments that make up the councils suggest horizontality in deliberations based on consensual decision-making. They express another form of democratic deliberation that broadens the contexts of deliberation beyond the liberal political field (BONET, 2017). Therefore, they allow democratic deepening. The experience of health councils, because of their deliberative character, enables direct participation in decision-making for the implementation of public policy. However, they already translate a new format of participation that includes the insertion of civil society organizations and participatory entities (MIGUEL, 2017). The recommendation, described in Resolution 453/2012, evidences this format that seeks to approximate participation and representation. The indication that the presence of representative entities among the segments that make up the councils is considered reveals the concern with crucial issues such as ensuring that representatives and decision-makers of public health policy do not distance themselves from their represented ones, and remain attentive to collective needs, besides the possibility of accountability and permanent dialogue between representatives and represented.

It cannot be affirmed that the presence of entities in the composition of the councils guarantees the effectiveness of the representation, but, undoubtedly, it favors the presence of collective interests, at least at the time of the appointment of the councilor, which may not occur among those who are not affiliated with institutions. Therefore, there is a "need to actively and permanently promote the expansion of the capacity for dialogue between representatives and represented" (MIGUEL, 2017, p. 114). It is worth mentioning that Resolution 453/2012 provides for the possibility of the existence of councils that do not contemplate entities 
among the segments in those municipalities where such organizations do not exist in sufficient numbers to occupy the available vacancies.

Besides the regulatory aspects highlighted in this study, other factors already evidenced in the literature interfere in the representativeness of the councils. The mechanisms used for choosing representatives by the entities that make up the councils are not very democratic; there is a distortion in the representation, both by the permanence of the same councilor for several mandates and by the fact that other segments occupy vacancies reserved for users (BISPO JÚNIOR, GERSCHMAN, 2015). Rezende and Moreira (2016) also highlight the need for deepening the bonds between the councilors and their representatives so that social participation is effective and transformative.

An important finding is that, despite the presence of civil society in balance with the other segments in the composition of health councils, when the election for president occurs, users appear in the minority. Thus, the study showed that most councils meet the parity criterion, maintaining a greater representation of civil society in its composition; however, this group is not representative when the election for president occurs. This feature is corroborated by studies that highlight the challenges for the realization of social participation, especially regarding the balance of political forces for decision-making (BRAVO; CORREIRA, 2012). The result indicates that even if parity is guaranteed in the composition of the councils, there is an imbalance in social participation when the segment of councils' presidents is identified.

Such a situation is detrimental to democratic exercise and hurts constitutional precepts, especially when considering the principle of administrative morality. A study conducted by Gavronski (2003) reinforces our findings when discussing the need to guarantee independence and autonomy between the segments since the councilors perform supervisory and control functions over health policy. The results obtained in this study indicate an advance in the democratization of health services, with growth in the participation of users who increasingly take on decision-making spaces, as is the case with councils. However, as evidenced, managers still occupy the presidency in most health councils, which can compromise effective control and supervision. These councils are in disagreement with a recent resolution of the National Health Council that expresses the impossibility of managers to occupy the position of president of the councils, to preserve the principle of segregation of the functions of execution and supervision of the Public Administration (BRASIL, 2017). 
Our findings add to other important aspects already evidenced in the literature that contribute to the imbalance of political forces within the councils: the asymmetry of knowledge among the segments present in the councils; meetings organized from the planning of managers, (situation especially aggravated when this segment occupies the presidency), and the limited investments in permanent education activities for social control in the Unified Health System (MARTINS et al, 2013; BATISTA et al, 2010; OUVERNEY, MOREIRA and RIBEIRO, 2016).

\section{Final considerations}

The study demonstrated the capillarity of the SIACS and the importance of Resolution 453/2012, which meets the need for councils to obtain parameters for its reformulation and functioning. The findings are positive concerning the large percentage of councils that are adequate to the recommendations of the National Health Council. Seven years after its publication, Resolution 453/2012 is still a reference for the reformulation of councils, considering the high percentage of councils that are adequate to the norm, regarding the parity criterion, presence of representative entities among the segments, and election for president. Thus, the National Health Council has been fulfilling an important role in strengthening municipal and state health councils. On the other hand, our study showed the regions where the highest rates of non-compliance with the parity criterion occur, which may guide priority actions of the control bodies to ensure compliance with Law 8,142/1990 and the recommendations of the National Health Council.

Based on this study, we consider it advisable to deepen the analyses on representativeness in health councils in Brazil and to identify which entities are represented in these spaces. In addition, it is interesting to observe if there is a renewal of the representation to contemplate diversity and broad conditions of participation. Future studies may also investigate whether the entities represented in the councils develop mechanisms to monitor and supervise the performance of their representatives. Furthermore, to verify the effectiveness of the representation, that is, whether those who occupy a seat on the council, in fact, dialogue with their entities and defend collective interests.

Although this article did not investigate the quality of the representation that occurs in health councils, it is worth highlighting the need to rescue its 
potential as spaces of new democratic constructions, which expand participation through direct deliberation on health policy. This research showed that the assumptions of Resolution 453/2012 for the reformulation of councils are aligned with the idea of representativeness that favors participatory parity and social balance in the management of health policy. However, due to recent changes in the infraconstitutional legislation that orders the functioning of the SUS, it is recommended that references for the operation of the councils be permanently updated to favor social participation in health.

A limitation of the study is the use of secondary data, which allows little control over the information collected. Because it is a database that is filled out directly by the health councils, different interpretations may occur depending on the respondents' understanding about the questions of Resolution 453/2012, adopted as variables in this study. Despite the scope and ease of access to the SIACS, it is little used in research, and at the time of the collection, it still did not cover all the health councils existing in Brazil.

\section{References}

ARCHANJO, Daniela Resende. Representação política: um diálogo entre a prática e a teoria. Rev. Sociol. Polit., Curitiba, v. 19, n. 38, p. 65-83, fev. 2011. Disponível em <http:// www.scielo.br/scielo.php?script=sci_arttext\&pid=S0104-44782011000100005\&lng=pt\&nrm= iso>. Acesso em 20 nov. 2018.

AVRITZER, Leonardo. A qualidade da democracia e a questão da efetividade da participaçáo: mapeando o debate. In: PIRES, R.R. (Org.). Efetividade das instituiçôes participativas no Brasil: estratégias de avaliação. Brasília: Ipea, 2011. p. 124-135.

AVRITZER, Leonardo; MARONA, Marjorie. A Tensão entre Soberania e Instituiçōes de Controle na Democracia Brasileira. Dados, Rio de Janeiro, v. 60, n. 2, p. 359-393, Apr. 2017. Disponível em <http://www.scielo.br/scielo.php?script=sci_arttext\&pid=S001152582017000200359\&lng=en\&nrm=iso>. Acesso em $12 \mathrm{dez} .2018$.

BATISTA, Adriana Aparecida et al. A contribuição da pesquisa avaliação para o processo de implementação do controle social no SUS. Saúde Soc. São Paulo, v. 19, n. 14, p. 784-793, 2010. BISPO JUNIOR, José Patrício; GERSCHMAN, Sílvia. Legitimidade da representação em instâncias de participação social: o caso do Conselho Estadual de Saúde da Bahia, Brasil. Cad. Saúde Pública, Rio de Janeiro, v. 31, n. 1, p. 183-193, jan. 2015. Disponível em <http://www. scielo.br/scielo.php?script=sci_arttext\&pid=S0102-11X2015000100183\&lng=pt\&nrm=iso>. Acesso em 04 dez. 2019. http://dx.doi.org/10.1590/0102-311X000862 
BONET, Antoni Aguiló. Fazer política através do espelho: vislumbres de outras democracias à luz dos indignados In: SANTOS, B. S.; MENDES, J. M. (Org.) Demodiversidade: imaginar novas possibilidades democráticas. Lisboa: Ediçôes 70. 2017. p. 207-232.

BRASIL. Constituição da República Federativa do Brasil [recurso eletrônico]. Brasília: Supremo Tribunal Federal. Secretaria de Documentação, 2019. 533 p. Disponível em: https://www.stf. jus.br/arquivo/cms/legislacaoConstituicao/anexo/CF.pdf. Acesso em 28 nov. 2019.

Lei $n^{\circ} 8142$, de 28 de dezembro de 1990. Dispóe sobre a participação da comunidade na gestão do Sistema Único de Saúde (SUS) e sobre as transferências intergovernamentais de recursos financeiros na área da saúde e dá outras providências. Brasília, DF: Diário Oficial da Uniāo. 29 dez. 1990. Disponível em http://www.planalto.gov.br/ccivil_03/leis/L8142.htm. Acesso em: 12 dez. 2018.

Instituto Brasileiro de Geografia e Estatística. Geografia do Brasil. Rio de Janeiro: SERGRAF; 1977.

. Acórdão n. 1.660, de 22 de março de 2011. Tribunal de Contas da União. Diário Oficial da União. 23 mar 2011.

. Conselho Nacional de Saúde. Resolução no 453, de 10 de maio de 2012. Aprova as diretrizes para instituição, reformulação, reestruturação e funcionamento dos Conselhos de Saúde. Diário Oficial da União. 11 Mai 2012a. Disponível em: http://bvsms.saude.gov.br/bvs/ saudelegis/cns/2012/res0453_10_05_2012.html. Acesso em: 15 dez. 2018.

. Conselho Nacional de Saúde. Resolução no 554, de 15 de setembro de 2017. Aprova Diretrizes para estruturação e funcionamento dos Conselhos de Saúde a serem aplicadas em conjunto com o previsto na Resolução CNS no 453/2012. Diário Oficial da União. 15 Jan 2018. Disponível em http://conselho.saude.gov.br/siacs/Reso554.pdf. Acesso em: 27 nov. 2019.

. Ministério da Saúde. Orientaçôes para os conselhos de saúde. Sistema de Acompanhamento dos Conselhos de Saúde. Brasília: Conselho Nacional de Saúde; 2012b. Disponível em: http:// bvsms.saude.gov.br/bvs/publicacoes/cartilha_orientacoes_conselhos_saude_siacs.pdf. Acesso em: 15 dez. 2018.

BRAVO, Maria Inês Souza; CORREIA, Maria Valéria Costa. Desafios do controle social na atualidade. Serv. Soc. Soc., São Paulo, n. 109, p. 126-150, Mar. 2012. Disponível em: <http:// www.scielo.br/scielo.php?script=sci_arttext\&pid=S0101-66282012000100008\&lng=en\&nrm =iso>. Acesso em 10 dez. 2018.

BUHLUNGU, Sakhela. O reinventar da democracia participativa na África do Sul. In: SANTOS, B. S.; (Org.). Democratizar a democracia: os caminhos da democracia participativa. Porto: Edições Afrontamento. 2003. p. 115-143. 
CARDOSO, Fábio Luiz Lopes. Cidadania, paridade de participação e o modelo de análise tridimensional de Nancy Fraser. Rev. Sem Aspas, Araraquara, v. 1, n. 1, p. 103-116, $1^{\circ}$ semestre 2012. Disponível em: https://periodicos.fclar.unesp.br/semaspas/article/view/6976. Acesso em: $10 \operatorname{dez} 2018$.

COELHO, Juliana Sousa. Construindo a participação social no SUS: um constante repensar em busca de equidade e transformação. Saúde soc., São Paulo, v. 21, supl. 1, p. 138-151, May 2012. Disponível em: <http://www.scielo.br/scielo.php?script=sci_arttext\&pid=S0104$12902012000500012 \& \operatorname{lng}=\mathrm{en} \& \mathrm{nrm}=\mathrm{iso}>$. Acesso em: $05 \mathrm{dez} .2018$.

COTTA, Rosângela Minardi Mitre et al. Controle social no Sistema Único de Saúde: subsídios para construção de competências dos conselheiros de saúde. Physis, Rio de Janeiro, v. 20, n. 3, p. 853-872, 2010. Disponível em: <http://www.scielo.br/scielo.php?script=sci_ arttext\&pid=S0103-73312010000300009\&lng=en\&nrm=iso>. Acesso em: 15 dez. 2018.

DIB ZAMBON, Vera.; OGATA Márcia Niituma. Configuraçóes dos Conselhos Municipais de Saúde de uma região no Estado de São Paulo. Rev. Esc. Enferm.USP., São Paulo, v. 45, n. 4, p. 890-897, 2011. Disponível em: http://www.scielo.br/pdf/reeusp/v45n4/v45n4a14.pdf. Acesso em 15 dez. 2018.

DURÁN, Paulo Renato Flores; GERSCHMAN, Silvia. Desafios da participação social nos conselhos de saúde. Saúde soc., São Paulo, v. 23, n. 3, p. 884-896, 2014. http://www.scielo.br/ pdf/sausoc/v23n3/0104-1290-sausoc-23-3-0884.pdf Acesso em 15 dez. 2018.

FRASER, Nancy. Reconhecimento sem ética?. Lua Nova, São Paulo, n. 70, p. 101-138, 2007. Disponível em: https://dx.doi.org/10.1590/S0102-64452007000100006. Acesso 13 dez. 2018.

GAVRONSKI, Alexandre Amaral. Conselhos de Saúde, democracia participativa e a inconstitucionalidade da presidência nata. Rev. direito sanit., São Paulo, v. 4, n. 2, p. 82-106, 2003. Disponível em: http://www.revistas.usp.br/rdisan/article/view/81186>. Acesso em 23 dez. 2018.

GUIZARDI, Francini Lube; PINHEIRO, Roseni. Dilemas culturais, sociais e políticos da participação dos movimentos sociais nos Conselhos de Saúde. Ciênc. saúde coletiva, Rio de Janeiro, v. 11, n. 3, p. 797-805, set. 2006. Disponível em: <http://www.scielo.br/scielo.php?script=sci_ arttext\&pid=S1413-81232006000300027\&lng=pt\&nrm=iso $>$. Acesso em 5 nov. 2018.

GUIZARDI, Francine Lube. A autocrítica necessária: notas sobre os desafios do controle social na saúde. Rev Eletron de Comum Inf Inov Saúde, Rio de Janeiro, v. 9, n. 3, p. 1-7, 2015. Disponível em: https://www.reciis.icict.fiocruz.br/index.php/reciis/article/view/1028/1978. Acesso em 5 nov 2018

GURZA LAVALlE, Adrián; HOUTZAGER Peter P; CASTELLO Graziela. Democracia, pluralização da representação e sociedade civil. Lua Nova, v. 67, p. 49-103, 2006. 
ISUNZA VERA, Ernesto; GURZA LAVALLE, Adrián. La innovación democrática en América Latina: tramas y nudos de la representación, la participación y el control social. México: Centro de Investigaciones y Estudios Superiores em Antropología Social, Universidad Veracruzana. 2010. LIMA, Dartel Ferrari de; LIMA, Lohran Anguera. O controle social no Sistema Único de Saúde: um olhar crítico à Resolução no 453/2012. Saúde debate, Rio de Janeiro, v. 41, n. 115, p. 1168-1176, Dec. 2017. Disponível em <http://www.scielo.br/scielo.php?script=sci_ arttext\&pid=S0103-11042017000401168\&lng=en\&nrm=iso >. Acesso em 13 dez. 2018.

LUCHMANN, Lígia Helena Hahn; ALMEIDA, Carla; GIMENES, Éder Rodrigo. Gênero e Representação Política nos Conselhos Gestores no Brasil. Dados, Rio de Janeiro, v. 59, n. 3, p. 789-822, setembro de 2016. Disponível em <http://www.scielo.br/scielo.php?script=sci_ arttext\&pid=S0011-52582016000300789\&lng=en\&nrm=iso>. Acesso em 01 dez. 2018.

LUCHMANN, Lígia Helena Hahn. A representação no interior das experiências de participação. Lua Nova, v. 70, p. 139-170, 2007. Disponível em <http://www.scielo.br/scielo. php?script=sci_arttext\&pid=S0011-52582016000300789\&lng=en\&nrm=iso $>$. Acesso em 01 dez. 2018.

MARTINS, Camila Sartori et al. Conhecimento dos usuários, trabalhadores da saúde e gestores sobre conselheiros e Conselhos de Saúde. Saúde em Debate, Rio de Janeiro, v. 37, n. 98, p. 437445, jul/set 2013. Disponível em http://www.scielo.br/pdf/sdeb/v37n98/a07v37n98.pdf. Acesso em 09 dez. 2019.

MENDES, Denise Cristina Vitale Ramos. Representação política e participação: reflexôes sobre o déficit democrático. Rev. katálysis, Florianópolis, v. 10, n. 2, p. 143-153, Dec. 2007. Disponível em <http://www.scielo.br/scielo.php?script=sci_arttext\&pid=S1414-49802007000200002\&ln $\mathrm{g}=\mathrm{en} \& \mathrm{nrm}=\mathrm{iso}>$. Acesso em $15 \mathrm{dez} .2018$

MIGUEL, Luis Felipe. Resgatar a participação: democracia participativa e representação política no debate contemporâneo. Lua Nova, v. 100, p. 83-118. 2017. Disponível em https:// dx.doi.org/10.1590/0102-083118/100. Acesso 7 dez. 2018.

MOREIRA, Marcelo Rasga; ESCOREL, Sarah. Conselhos Municipais de Saúde do Brasil: um debate sobre a democratização da política de saúde nos vinte anos do SUS. Ciênc. saúde coletiva, Rio de Janeiro, v. 14, n. 3, p. 795-806, jun. 2009. Disponível em <http://www.scielo. br/scielo.php?script $=$ sci_arttext $\&$ pid $=$ S1413-81232009000300015\&lng=pt \&nrm $=$ iso $>$. Acesso em 25 nov. 2018.

MÜLLER NETO, Julio Strubing; ARTMANN, Elizabeth. Discursos sobre o papel e a representatividade de conferências municipais de saúde. Cad. Saúde Pública. Rio de Janeiro, v. 30, n. 1, p. 68-78, jan. 2014. Disponível em <http://www.scielo.br/scielo.php?script=sci_ arttext\&pid=S0102-311X2014000100068\&lng=pt\&nrm=iso $>$. Acesso em 04 dez. 2019. http://dx.doi.org/10.1590/0102-311X00136012 
OUVERNEY, Assis Mafort; MOREIRA, Marcelo Rasga; RIBEIRO, José Mendes. Democratização e educação permanente; percepção de egressos do QualiConselhos sobre contribuiçôes aos conselhos de saúde. Saúde Debate. Rio de Janeiro, v. 40, n. especial, p. 186200, dez 2016.

PAIM, Jairnilson Silva. Sistema Único de Saúde (SUS) aos 30 anos. Ciên. Saúde coletiva. Rio de Janeiro, v. 23, n. 6, p. 1723-1728, 2018. Disponível em http://www.scielo.br/scielo. php?script=sci_arttext $\&$ pid $=S 1413-81232018000601723 \& \operatorname{lng}=$ pt $\&$ nrm $=$ iso. Acesso em 26 nov. 2019.

RAMOS, Michelle de Fátima et al. Conselhos setoriais: perfil dos conselheiros e sua influência na tomada de decisão. Saude soc., São Paulo, v. 21, supl. 3, p. 61-70, Dec. 2012. Disponível em <http://www.scielo.br/scielo.php?script=sci_arttext\&pid=S0104-12902012000700006\&lng=e n\&nrm=iso>. Acesso em 10 out. 2018.

REZENDE, Raphael Batista; MOREIRA, Marcelo Rasga. Relaçôes entre representação e participação no Conselho Municipal de Saúde do Rio de Janeiro: segmento dos usuários. 20132014. Ciênc. saúde colet., Rio de Janeiro, v. 21, n. 5, p., mai. 2016. Disponível em https://www. scielosp.org/article/csc/2016.v21n5/1409-1420/. Acesso em 29 nov. 2019.

ROLIM, Leonardo Barbosa; CRUZ, Rachel de Sá Barreto Luna Callou; SAMPAIO, Karla Jimena Araújo de Jesus. Participação popular e o controle social como diretriz do SUS: uma revisão narrativa. Saúde debate, Rio de Janeiro, v. 37, n. 96, p. 139-147, Mar. 2013. Disponível em <http://www.scielo.br/scielo.php?script=sci_arttext\&pid=S0103-11042013000100016\&lng $=$ en\&nrm=iso $>$. Acesso em 05 nov. 2018.

ROUQUAYROL, Maria Zélia; ALMEIDA FILHO, Naomar. Epidemiologia e saúde. Rio de Janeiro: Guanabara Koogan. 2006.

RUBIO, Ximena de los Ángeles Barros; UGARTE, Victoria Soledad Rivera. Normatividad y visión societal en políticas públicas participativas de salud en Centroamérica. Rev. katálysis, Florianópolis, v. 17, n. 2, p. 242-251, Dec. 2014. Disponível em <http://www.scielo. br/scielo.php?script $=$ sci_arttext $\&$ pid $=\$ 1414-49802014000200242 \& \operatorname{lng}=$ en $\& n r m=i s o>$. Acesso em 25 nov. 2018.

SANTANA, Vilma Sousa; CUNHA, Sérgio. Estudos Transversais. In: ALMEIDA FILHO N.; BARRETO, M. L.; (Org.). Epidemiologia \& Saúde: fundamentos, métodos, aplicaçóes. Rio de Janeiro: Guanabara Koogan. 2014. p. 186-193.

SANTOS, Boaventura Souza; AVRITZER, Leonardo. Introdução: para ampliar o cânone democrático. In: SANTOS, B.S.; (Org.). Democratizar a democracia: os caminhos da democracia participativa. Porto: Ediçóes Afrontamento; 2003. p. 35-69. 
SANTOS, Marta Alves. Lutas sociais pela saúde pública no Brasil frente aos desafios contemporâneos. Rev. katálysis, Florianópolis, v. 16, n. 2, p. 233-240, Dec. 2013. Disponível em <http://www.scielo.br/scielo.php?script=sci_arttext\&pid=S1414-49802013000200009\&ln $\mathrm{g}=\mathrm{en} \& \mathrm{nrm}=\mathrm{iso}>$. Acesso em 25 nov. 2019.

VENTURA, Carla Aparecida Arena et al. Cultura participativa: um processo de construçáo de cidadania no Brasil. Interface (Botucatu), Botucatu, v. 21, n. 63, p. 907-920, dezembro de 2017. Disponível em <http://www.scielo.br/scielo.php?script=sci_arttext\&pid=S1414$32832017000400907 \& \operatorname{lng}=$ en\&nrm=iso>. Acesso em 13 dez. 2018.

\section{Notes}

${ }^{1}$ This work was carried out with the support of the Coordenação de Aperfeiçoamento de Pessoal de Nível Superior - Brazil (CAPES) - Financing Code 001, to which the authors thank.

${ }^{2}$ The term individualized was proposed by Almeida Filho and Barreto (2014) in contrast to the type of collection designated by the adjective "aggregate" and to distinguish it from the psychological process of "individualization". 


\section{Resumo}

Participação social: um olhar sobre a representatividade nos conselhos de saúde no Brasil, a partir da Resolução 453/2012

O texto aborda a representatividade nos conselhos de saúde no Brasil, a partir de diretrizes propostas pelo Conselho Nacional de Saúde. O objetivo do estudo foi verificar a adequação dos conselhos aos critérios descritos na Resolução 453/2012, que demonstram a representatividade dos segmentos que compóem o coletivo. Foi realizado estudo descritivo, do tipo transversal, durante os meses de maio e junho de 2017. A população do estudo foi composta pelos conselhos de saúde cadastrados no Sistema de Acompanhamento dos Conselhos de Saúde, de acesso público e disponível na internet. Os resultados obtidos foram organizados considerando a distribuição geográfica dos conselhos. Foram identificadas as regióes com maiores índices de descumprimento do critério de paridade. Ficou demonstrado que as diretrizes para reformulação dos conselhos estão alinhadas a noção de representatividade, porém, não são garantia para a efetividade da representação. Estudos futuros poderão aprofundar as análises sobre a representatividade nos conselhos de saúde no Brasil, e identificar quais mecanismos são adotados pelas entidades para garantir efetividade da representação, bem como se ocorre renovação da representação. É recomendável que as normas que ordenam o funcionamento dos conselhos sejam permanentemente atualizadas para favorecer a participação social na saúde.

> Palavras-chave: Conselhos de saúde. Participação da comunidade. Sistema Único de Saúde. Brasil. 